\title{
PERUBAHAN MEDIA BERMAIN DAN PERGESERAN GAYA HIDUP ANAK DI LINGKUNGAN BULU KECAMATAN MATTIRO BULU KABUPATEN PINRANG
}

\author{
Oleh: Mutmainnah Arham, Andi Agustang*2 \\ ${ }^{12}$ Program Studi pendidikan Sosiologi Fakultas Ilmu Sosial dan Hukum \\ Universitas Negeri Makassar \\ Email: Mutmainnaharham@gmail.com ${ }^{1}$,andi.agustang@unm.ac.id ${ }^{2}$
}

\begin{abstract}
Abstrak
Penelitian ini bertujuan untuk mengetahui 1) bagaimana perubahan media bermain anak di Lingkungan Bulu Kecamatan Mattiro Bulu Kabupaten Pinrang, 2) bagaimana bentuk pergeseran gaya hidup anak di Lingkungan Bulu Kecamatan Mattiro Bulu Kabupaten Pinrang, 3) dampak perubahan media bermain terhadap pergeseran gaya hidup anak. Jenis penelitian ini merupakan penelitian kualitatif. Jumlah informan dalam penelitian ini sebanyak 13 orang yang ditentukan melalui teknik purposive sampling. Teknik pengumpulan data yaitu observasi, wawancara, dan dokumentasi. Pemeriksaan keabsahan data dilakukan dengan menggunakan member checking. Hasil penelitian menunjukkan bahwa 1) perubahan media bermain anak di Lingkungan Bulu terjadi karena perubahan lingkungan geografis dan adanya penemuan-penemuan baru, perubahan media bermain anak-anak terjadi dalam rentan waktu 2 hingga 5 tahun. 2) pergeseran gaya hidup anak di Lingkungan Bulu yang pertama, adalah pergeseran ke gaya hidup Sedenter. Kedua, pergeseran ke gaya hidup modern, 3) dampak perubahan media bermain terhadap pergeseran gaya hidup anak di Lingkungan Bulu ada dua yaitu dampak negatif dan juga dampak positif.
\end{abstract}

Kata Kunci: Perubahan Media Bermain, Pergeseran Gaya Hidup, Anak-Anak, Lingkungan Bulu

\section{PENDAHULUAN}

Gaya hidup adalah sikap, nilai, dan tingkah laku bagaimana individu menghabiskan waktunya dengan melakukan aktivitas yang dapat berubah karena dipengaruhi kondisi dan lingkungan. Gaya hidup berkaitan erat dengan perkembangan zaman dan teknologi (Agustang, 2021b). Perkembangan zaman semakin maju tentu memberikan dampak positif dan juga negatif apabila kita tidak mampu mengimbangi perkembangan tersebut. Terutama kemajuan teknologi yang begitu pesat telah merambah ke daerah perkotaan dan daerah pedesaan, yang kita lihat saat ini banyak yang sudah memiliki handphone baik orang dewasa bahkan anak-anak sekalipun. Handphone dijadikan media bermain bagi anak-anak sekarang ini. Tidak seperti dulu anak-anak bermain menggunakan media bermain yang sangat sederhana. 
Di lingkungan Bulu, Kecamatan Mattiro bulu gaya hidup anak-anak di pengaruhi oleh media bermain yang baru faktanya anak remaja dan juga anak yang masih dibawah usia 13 tahunpun sudah memiliki handphone, sehingga menyebabkan media bermain tradisional jarang lagi ditemui di lingkungan Bulu. Adapun beberapa anak mengetahui permainan tradisional tapi tidak mengetahui aturan bermain dalam permainan, hal tersebut akhirnya mempengaruhi anak untuk tidak menjalankan permainan tersebut dan mencari permainan yang lebih menarik.

Selain itu anak-anak di lingkungan Bulu, yang masih duduk di bangku dasar banyak yang mulai berani menunjukkan ketertarikannya terhadap lawan jenis, padahal wajarnya anak seusia tersebut belum saatnya merasakan gejala-gejala tersebut. Hal ini terjadi akibat pengaruh dari perubahan sosial sebagai akibat dari konsumsi media bermain yang tidak disaring. Media bermain anak saat ini susah dibedakan dengan media bermain untuk orang dewasa. Bahkan anak dan orang dewasa banyak bermain bersama sehingga anak bisa saja dengan mudah meniru gaya hidup orang dewasa (Oruh et al., 2019).

Anak-anak di lingkungan bulu mengalami banyak pergeseran gaya hidup disebabkan karena media bermain yang berubah dan yang paling terlihat adalah gaya hidup yang tidak sehat dikarenakan media bemain menggunakan handphone sehingga terkadang anak lupa terhadap waktu yang seharusnya mereka pergunakan untuk istirahat dan tentu hal tersebut berdampak kepada kesehatan anak. Anak juga akan susah untuk bangun tepat waktu untuk hadir kesekolah.

Karena media bermain yang berubah gaya hidup konsumtif juga muncul, banyak anak remaja yang membeli produk dalam game yang sebenarnya tidak penting dan menghabiskan banyak uang untuk kepuasan dalam bermain (Mawuntu 2018). Serta munculnya bahasa kasar yang tidak sepantasnya diucapkan oleh anak-anak hal ini di dapatkan dari media bermain yang tidak disaring secara baik.

Akibat perubahan media bermain, anak-anak di lingkungan bulu mulai jarang melakukan interaksi secara langsung dengan teman-teman sebayanya, mereka lebih memilih untuk bermain di dalam rumah, meskipun ketika anak-anak hang-out lagi-lagi hampir semuanya disibukkan dengan handphone. Penggunaan handphone dan media sosial sebagai media bermain anak merupakan salah satu bentuk pemanfaatan teknologi, tetapi bukan berarti bahwa teknologi dapat disalahkan begitu saja. Teknologi memang harus sudah dikenalkan pada anak sedini mungkin demi menungjang ketertarikan dan agar anak dapat mengarahkan dirinya sendiri untuk mengenal lebih jauh lingkungan disekitarnya (Ramlafatma et al., 2021).

Adapaun alasan mengapa penulis tertarik untuk melakukan penelitian tentang "Perubahan Media Bermain dan Pergeseran Gaya Hidup Anak Di Lingkungan Bulu Kecamatan Mattiro Bulu Kabupaten Pinrang" yaitu karena di daerah ini terlihat anakanak mengalami perubahan media bermain dan terjadi pergeseran gaya hidup yang akhirnya dapat menimbulkan perilaku menyimpang dan menimbulkan masalah sosial. Tetapi hal tersebut beriringan dengan pergeseran gaya hidup dan dampak yang positif. 
Hal tersebut dapat terjadi akibat media bermain yang tidak sesuai dengan perkembangan anak. Maka dari itu penulis lebih tertarik untuk mengkaji lebih dalam dan menyeluruh terkait pengaruh perubahan media bermain yang menyebabkan pergeseran gaya hidup anak di Lingkungan Bulu.

\section{METODE PENELITIAN}

Pendekatan penelitian yang digunakan dalam penelitian ini adalah pendekatan deskriptif dengan jenis penelitian kualitatif. Penelitian ini berupaya untuk mengambarkan bagaimana perubahan media bermain dan pergeseran gaya hidup anak di lingkungan Bulu Kecamatan Mattiro Bulu Kabupaten Pinrang. Pendekatan deskriptif adalah data yang dikumpulkan berupa kata-kata, gambar, dan bukan angka-angka. Semua yang dikumpulkan berkemungkinan menjadi kunci terhadap apa yang sudah diteliti (Agustang, 2021a)

Adapun tahap-tahap penelitan yang dilakukan dalam penelitian ini secara garis besar yaitu tahap pra penelitian, tahap penelitian, dan tahap akhir. Jumlah informan dalam penelitian ini sebanyak 13 orang yang ditentukan melalui teknik purposive sampling. Teknik pengumpulan data yaitu observasi, wawancara, dan dokumentasi. Pemeriksaan keabsahan data dilakukan dengan menggunakan member checking. Teknik analisis data meliputi reduksi data, penyajian data, dan kesimpulan (Agustang, 2011).

\section{PEMBAHASAN}

\section{Perubahan Media Bermain Anak di Lingkungan Bulu}

Menurut Hurlock dalam (Agustang \& Oruh, 2021) Bermain merupakan suatu kegiatan yang dilakukan oleh anak dengan spontan, perasaan gembira, tidak memiliki tujuan ekstrinsik, melibatkan peran aktif anak, memiliki hubungan sistematik dengan hal-hal di luar bermain seperti perkembangan kreativitas, dan merupakan interaksi antara anak dengan lingkungannya, serta memungkinkan anak untuk beradaptasi dengan lingkungan tersebut. Bermain bagi anak sangat membantu dalam proses pengembangan aspek sosial, kognitif dan emosinya.

Sama halnya dengan (Oruh et al., 2019) bahwa media sendiri merupakan alat atau sarana yang digunakan. Jadi dapat disimpulkan bahwa perubahan media bermain adalah perubahan alat atau sarana yang digunakan untuk bermain bagi anak. Perubahan media bermain ini perubahan dari permainan tradisional ke permainan modern yang dimana Permainan tradisional terbuat dari alat-alat sederhana seperti kayu, bambu dan sebagainya. Permainan tradisional dikenal sebagai permainan rakyat yang merupakan sebuah kegiatan rekreatif yang tidak hanya bertujuan menghibur diri tetapi juga sebagai alat memelihara hubungan sosial serta untuk menambah budaya bangsa kita. Permainan modern tercipta dengan alat-alat canggih seperti komputer, handphone, dan saat ini sudah banyak anak-anak menyukai permainan modern. 
Perubahan media bermain anak yang terjadi dalam rentang waktu yang cukup lama membuat adanya pergeseran pada gaya hidup anak-anak di Lingkungan Bulu. Perubahan yang terjadi di masyarakat terjadi dikarenakan berbagai faktor salah-satunya karena adanya penemuan-penemuan baru, karena adanya penemuan-penemuan media bermain baru bagi anak-anak yang ada dilingkungan bulu yang kemudian menyebabkan pergeseran gaya hidup (Haniah et al., 2014).

Menurut Gillin dalam (Agustang, 1999b) perubahan sosial adalah perubahan yang terjadi sebagai suatu variasi dari cara hidup yang telah diterima karena adanya perubahan kondisi geografi, kebudayaan material, komposisi penduduk, ideologi, maupun adanya difusi atau penemuan-penemuan baru dalam masyarakat. Perubahan sosial itu adalah proses perubahan yang terjadi dalam sistem sosial masyarakat dalam jangka waktu berbeda, dan kemudian mempengaruhi unsur-unsur dalam sistem sosial, lebih tepatnya, terdapat perbedaan-perbedaan tertentu dalam jangka waktu berlainan.

Pandangan sztompka dalam (Agustang, 1999a) mengenai perubahan sosial ia menaruh penekanan pada perubahan yang terjadi pada sistem masyarakat dalam jangka waktu yang berbeda, dan kemudian perubahan ini membawa pengaruh terhadap unsur-unsur dalam sistem, keluarga, pola hidup, cara berfikir, ekonomi, dan sebagainya yang kemudian membawa masyarakat pada keadaan yang baru. perubahan media bermain anak disebabkan oleh faktor perubahan lingkungan, penemuan-penemuan baru, dan juga tindak kriminalitas yang semakin banyak terjadi. Karena kondisi lingkungan tempat tinggal yang semakin berkurangnya lahan kosong ataupun lapangan untuk bermain anak-anak sehingga menjadi kekhawatiran para orang tua ketika anaknya bermain diluar ataupun di pinggir jalan, dan juga karena adanya penemuan media bermain baru sehingga orang tua tidak susah untuk mengawasi anaknya. Dan orang tua memiliki ketakutan ketika anaknya bermain diluar rumah dapat menjadi korban kejahatan, seperti penculikan dan pelecehan. Sehingga hal ini juga mendorong para orang tua untuk menyediakan media bermain baru yang lebih praktis untuk digunakan dan lebih menarik untuk anak-anak, dan penggunaannya tidak mesti diluar rumah. Anak-anak mulai meninggalkan permainan tradisonal dalam kurun waktu yang sudah cukup lama, dan kemudian karena perubahan ini sudah berlangsung cukup lama yang kemudian memberikan dampak kepada anak-anak di lingkungan Bulu.

\section{Bentuk Pergeseran Gaya Hidup Anak di Lingkungan Bulu}

Gaya hidup adalah bagaimana seseorang memilih untuk bagaimana ia hidup menggunakan dan memanfaatkan waktunya. Gaya hidup dan karakteristik berbeda meskipun saling berhubungan, kepribadian merefleksi karakteristik internal dari konsumen, gaya hidup menggambarkan manifestasi eksternal dari karakteristik tersebut, yaitu perilaku seseorang. 
Menurut Chaney dalam (Agustang, Andi; Oruh, 2017) gaya hidup merupakan pola-pola tindakan yang membedakan satu orang dengan yang lain. Mencakup sekumpulan kebiasaan, pandangan dan pola-pola respon terhadap hidup, serta terutama perlengkapan untuk hidup seperti cara berpakaian, cara kerja, pola konsumsi, bagaimana individual mengisi kesehariannya merupakan unsur-unsur yang membentuk gaya hidup.

Menurut (Mutiara et al., 2020) gaya hidup adalah cara hidup individu yang diidentifikasikan oleh bagaimana orang menghabiskan waktu mereka (aktivitas), apa yang mereka anggap penting dalam hidupnya (ketertarikan) dan apa yang mereka pikirkan tentang dunia sekitarnya. Gaya hidup adalah bagaimana seseorang memilih untuk bagaimana ia hidup menggunakan dan memanfaatkan waktunya. Gaya hidup dan karakteristik berbeda meskipun saling berhubungan, kepribadian merefleksi karakteristik internal dari konsumen, gaya hidup menggambarkan manifestasi eksternal dari karakteristik tersebut, yaitu perilaku seseorang.

Pergeseran gaya hidup anak banyak didorong oleh faktor lingkungan sekitar, dan kondisi masyarakat, salah satu yang mendorong pergeseran gaya hidup anak karena adanya perubahan yang disebabkan oleh penemuan-penemuan baru dan kondisi geografis. Bentuk pergeseran gaya hidup anak bisa mengarah ke hal yang positif dan bisa sebaliknya, serta bisa memberikan dampak yang baik dan juga dapat memberikan dampak yang buruk. Bentuk pergeseran gaya hidup anak-anak yang dialamai di lingkungan bulu menjadi gaya hidup sedentary, dan gaya hidup modern. Adapun bentuk pergeseran gaya hidup anak di Lingkungan Bulu yang pertama

1) Gaya hidup sedentary, Pada dasarnya gaya hidup sedenter merupakan gaya hidup yang menunjukkan kebiasaan malas bergerak yang ditunjukkan seseorang, di mana orang tersebut lebih banyak menghabiskan waktunya dengan duduk atau berbaring dalam waktu yang lama dan sedikit melakukan aktivitas fisik dan yang membutuhkan energi lebih.

Costigan SA 2013. Menyatakan bahwa gaya hidup sedenter adalah kebiasaan seseorang yang tidak banyak melakukan aktivitas fisik atau tidak banyak melakukan gerakan. Gaya hidup sedenter berhubungan dengan aktivitas pada tingkat aktivitas fisik istirahat atau merupakan salah satu dari aktivitas ringan dengan pengeluaran energy expenditure setara 1-1,5 metabolic equivalent (Mahmuddin et al., 2020)

Gaya hidup modern, Di jaman sekarang ini yang serba modern dan praktis, menuntut masyarakat untuk tidak ketinggalan dalam segala hal termasuk dalam bidang teknologi. Banyak orang yang berlomba-lomba ingin menjadi yang terbaik dalam hal pemahaman teknologi.

Gaya hidup digital (digital lifestyle) adalah istilah yang seringkali digunakan untuk menggambarkan gaya hidup modern yang sarat dengan teknologi informasi. Teknologi informasi yang sangat berperan untuk mengefisienkan segala sesuatu yang 
kita lakukan, baik di masa kini maupun masa depan, dengan satu tujuan yaitu mencapai efisiensi dan produktivitas maksimum. Tentu tidak dapat dibantah lagi, bahwa teknologi informasi memang berperan besar dalam meningkatkan efisiensi dalam kehidupan Oruh, S. (2021, December 4).

Gaya hidup modern membuat individu menjadi lebih terbuka terhadap perkembangan dan perubahan, dan banyak belajar hal-hal baru. Hal ini dikarenakan kesadaran diri untuk belajar semakin besar karena individu sadar bahwa dunia semakin berkembang.

Gaya hidup modern merupakan kebiasaan atau pola tingkah laku sehari-hari manusia yang sesuai dengan tuntutan zaman yang serba modern dan praktis, menuntut masyarakat untuk tidak ketinggalan dalam segala hal. Anak-anak di Lingkungan Bulu menjadi anak-anak yang interaksinya semakin luas, tidak peka dengan lingkungan sekitar, Wawasan atau hal-hal yang tidak sesuai dengan dunia anak, dan serba instan. Dan gaya hidup digital.

\section{Dampak perubahan media bermain terhadap gaya hidup anak di Lingkungan Bulu}

Segala perubahan dan kemajuan saat ini tidak dapat dipisahkan dari kehidupan masyarakat. Berbagai perubahan terjadi di kehidupan masyarakat salah satunya kemajuan teknologi ini. saat ini dunia terasa semakin sempit karena kita dapat melihat segala yang terjadi di belahan dunia melalui perkembangan teknologi dan media komunikasi. Perubahan media bermain anak-anak banyak di dorong karena kemajuan teknologi dan media komunikasi (Agustang, Andi; Oruh, 2017)

Kemajuan teknologi ini menyebabkan terjadinya perubahan-perubahan besar pada kehidupan masyarakat khususnya anak-anak. Jika dipandang dari harga, media seperti hp bukanlah barang yang murah sehingga hanya digunakan oleh orang-orang yang berkepentingan saja, tetapi faktanya anak-anak dan remaja pun sudah menggunakannya bahkan menjadi media bermain untuk mereka. Akibatnya, segala informasi baik itu yang positif atau yang negati dapat di akses dengan mudah.

(Agustang et al., 2021) Mengemukakan bahwa media komunikasi memiliki dampak terhadap anak. Dari hal tersebut dapat di golongkan menjadi 2 golongan, yaitu dampak positi dan dampak negatif. Dampak positif, 1) Anak-anak dapat menggunakan perangkat lunak seperti program-program pengetahuan untuk menambah wawasan. 2) Membuat anak-anak lebih tertarik untuk belajar. 3) Memudahkan anak-anak untuk mendapatkan lebih banyak ilmu tambahan lewat internet yang diakses melalui media komunikasi.

Dampak negatif, 1) Anak-anak bisa ketergantungan dengan teknologi dan media komunikasi. 2) Anak-anak cenderung mengerjakan tugas sendiri dengan bantuan internet daripada belajar kelompok. 3) Dapat berpengaruh pada pergaulan karena 
kurang kontrol dari orang tua. 4) Anak-anak bisa bebas dalam mengakses semua situssitus yang tidak baik. 5) Mengurangi sifat sosial manusia karena cenderung lebih suka berhubungan lewat internet atau melalui media daripada bertemu secara langsung . 6) Kemungkinan besar anak-anak tanpa sepengetahuan orang tua dapat mengakses games-games yang mengandung unsur-unsur kekerasan dan agresivitas. 7) Media komunikasi memberi banyak manfaat bagi kehidupan kalau digunakan secara bijak, seperti membantu dalam proses belajar. Selain itu media komunikasi dikalangan anakanak juga memberi dampak yang negatif, seperti membuat anak-anak menjadi malas belajar, merasa ketergantungan dengan media handphone, dan dampak yang paling bahaya yaitu merusak kesehatan mata karena terlalu sering memandangi layar HP, komputer dan televisi. Maka dari itu dalam mengurangi dampak dari penggunaan media komunikasi ini perlu adanya pengawasan dari orang tua.

Anak-anak di Lingkungan Bulu Kecamatan Mattiro Bulu Kabupaten Pinrang cenderung bergantung pada media teknologi, mengerjakan tugas menggunakan internet tanpa kerja sama atau membaca buku, mengurangi sifat sosial anak-anak dengan dunia nyata, anak-anak mendapatkan atau menonton video atau game yang mengandung unsur kekerasan, dan mencontoh perilaku ataupun perkataan kasar yang mereka dapat di media. Dampak positif anak-anak dapat menambah wawasan pengetahuan mereka, membuat anak-anak mendapatkan banyak ilmu tambahan, interaksi sosial anak-anak yang semakin luas dan tidak terbatas. Anak-anak mengidamkan barang-barang sesuai dengan perkembangan zaman dan apa yang ia liat di media atau hp.

\section{PENUTUP}

Berdasarkan hasil penelitian yang dilakukan oleh peneliti, terhadap perubahan media bermain dan pergeseran gaya hidup anak di Lingkungan Bulu Kecamatan Mattiro Bulu Kabupaten Pinrang, maka dapat disimpulkan sebagai berikut : 1) Perubahan media bermain anak-anak di Lingkungan Bulu terjadi karena disebabkan oleh faktor perubahan lingkungan geografis dan penemuan-penemuan baru yang ada di masyarakat. Anak-anak di Lingkungan Bulu meninggalkan permainan tradisional dalam rentan waktu yang cukup lama, 2 hingga 5 tahun. mereka menganggap bahwa bermain menggunakan media bermain modern lebih praktis dan menyenangkan tanpa harus membuang banyak energy. 2) Bentuk pergeseran gaya hidup anak di Lingkungan Bulu yang pertama, adalah pergeseran ke gaya hidup Sedenter. Kedua, pergeseran ke gaya hidup modern. 3) Dampak perubahan media bermain terhadap gaya hidup anak di Lingkungan Bulu Kecamatan Mattiro Bulu Kabupaten Pinrang. Dampak negatif yang pertama, anak-anak bergantung pada media teknologi. Kedua, mengerjakan tugas menggunakan internet tanpa kerja sama atau membaca buku. Ketiga, mengurangi sifat sosial anak- anak dengan dunia nyata. Keempat, mengakses hal-hal yang tidak sesuai dengan umur. anak-anak mendapatkan atau menonton video atau game yang 
mengandung unsur kekerasan, dan mencontoh perilaku ataupun perkataan kasar yang mereka dapat di media. Kelima, Anak-anak mengidamkan barang-barang sesuai dengan perkembangan zaman dan apa yang ia liat di media atau hp. Dampak positif yang Pertama, anak-anak dapat menambah wawasan pengetahuan mereka, membuat anakanak mendapatkan banyak ilmu tambahan. Kedua, interaksi sosial anak-anak yang semakin luas dan tidak terbatas.

\section{DAFTAR PUSTAKA}

Agustang, Andi; Oruh, S. (2017). Factors affecting of heropnam of mental disorders in Dadi Regional Hospital in South Sulawesi Province Key models of public service in the wide administratif region View project. 97(11), 233-244.

https://www.researchgate.net/publication/318777079

Agustang, A. (1999a). INTERAKSI SOSIAL DAN PERUBAHAN STRUKTUR

KOMUNITAS. Universitas Padjadjaran Bandung.

Agustang, A. (1999b). Interaksi Sosial dan Perubahan Struktur Komunitas (Studi Pada Masyarakat Kawasan Industri Makassar Sulawesi Selatan).

Agustang, A. (2011). Pendekatan Penelitian Kualitatif dan Kuantitatif Suatu Tinjauan Kritis. In Makassar: Andira Publisher. Andira Publisher.

Agustang, A. (2021a). Filosofi Research Dalam Upaya Pengembangan Ilmu. OSF Preprints.

Agustang, A. (2021b). Teknologi Partisipasi Metode Fasilitasi Pembuatan Keputusan Partisipatif. OSF Preprints.

Agustang, A., \& Oruh, S. (2021). KESEJAHTERAAN PSIKOLOGIS (studi Pada Dewasa Madya Yang Belum Menikah Di Kota Makassar).

Agustang, A., Suardi, S., Putra, A. D. M., \& Oruh, S. (2021). Pemberdayaan Guru Mata Pelajaran Sosiologi Melalui Literasi Digital Berbasis Quick Response Code di Kecamatan Bissappu Kabupaten Bantaeng. Abdi: Jurnal Pengabdian Dan Pemberdayaan Masyarakat, 3(2), 175-188. https://doi.org/10.24036/abdi.v3i2.120

Haniah, S., Agustang, A., \& Samad, S. (2014). SOCIAL ACTION IN THE CLASSROOM: ANALYSIS OF EDUCATIONAL SOCIOLOGY ON INTERACTION BETWEEN TEACHER AND STUDENT IN SMP KARTIKA CHANDRA MAKASSAR. International Journal of Academic Research, 6(4).

Mahmuddin, H., Oruh, S., \& Agustang. Andi. (2020). PRIMARY HEALTH SERVICES IN THE PERSPECTIVE OF PARTICIPATORY GOVERNANCE.

Mutiara, I. A., Agustang, A., Adam, A., Upe, A., \& Equatora, M. A. (2020). The dynamics of prostitutes lives in metropolitan cities. Journal of Critical Reviews, 7(11), 928-931.

Oruh, S., Theresia, M., \& Agustang, A. (2019). KESEJAHTERAAN PSIKOLOGIS. Researchgate.Net.

Oruh, S. (2021, December 4). KAU MAU KEMANA (Refleksi Sosiologis terhadap Integritas Upaya Kesehatan Jiwa). https://doi.org/10.31219/osf.io/ut6jq

Ramlafatma, R., Oruh, S., \& Agustang, A. (2021). Efektivitas Pendidikan Moral Dalam Pembentukan Karakter Siswa Di TK Islam Terpadu Asa Sumbawa. Jurnal Ilmiah Mandala Education, 7(4). https://doi.org/10.36312/jime.v7i4.2433 